\title{
Mutations and polymorphisms in FSH receptor: functional implications in human reproduction
}

\author{
Swapna S Desai ${ }^{1}$, Binita Sur Roy ${ }^{2}$ and Smita D Mahale ${ }^{1,2}$ \\ ${ }^{1}$ Division of Structural Biology and ${ }^{2}$ ICMR Biomedical Informatics Centre, National Institute for Research in \\ Reproductive Health (Indian Council of Medical Research), Jehangir Merwanji Street, Parel, Mumbai 400 012, India \\ Correspondence should be addressed to S D Mahale; Email: smitamahale@hotmail.com
}

\begin{abstract}
FSH brings about its physiological actions by activating a specific receptor located on target cells. Normal functioning of the FSH receptor (FSHR) is crucial for follicular development and estradiol production in females and for the regulation of Sertoli cell function and spermatogenesis in males. In the last two decades, the number of inactivating and activating mutations, single nucleotide polymorphisms, and spliced variants of $F S H R$ gene has been identified in selected infertile cases. Information on genotype-phenotype correlation and in vitro functional characterization of the mutants has helped in understanding the possible genetic cause for female infertility in affected individuals. The information is also being used to dissect various extracellular and intracellular events involved in hormone-receptor interaction by studying the differences in the properties of the mutant receptor when compared with WT receptor. Studies on polymorphisms in the FSHR gene have shown variability in clinical outcome among women treated with FSH. These observations are being explored to develop molecular markers to predict the optimum dose of FSH required for controlled ovarian hyperstimulation. Pharmacogenetics is an emerging field in this area that aims at designing individual treatment protocols for reproductive abnormalities based on FSHR gene polymorphisms. The present review discusses the current knowledge of various genetic alterations in $F S H R$ and their impact on receptor function in the female reproductive system.

Reproduction (2013) 146 R235-R248
\end{abstract}

\section{Introduction}

Follicle-stimulating hormone (FSH), luteinizing hormone (LH), and thyroid-stimulating hormone (TSH) are glycoproteins secreted by the anterior pituitary. They are heterodimers comprising a common $\alpha$-subunit and a hormone-specific $\beta$-subunit that contributes to receptorbinding specificity (Pierce \& Parsons 1981). FSH and LH are under the regulation of gonadotropin-releasing hormone $(\mathrm{GNRH})$ and in turn regulate gonadal functions in males and females by activating their cognate receptors. FSH receptors (FSHR) along with other glycoprotein hormone receptors (LH/CGR and TSHR) form a subgroup of G-protein-coupled receptors (GPCR). FSH binds to its receptors expressed on the membrane of granulosa cells (GCs) in the ovary and Sertoli cells in the testis to bring about folliculogenesis (Richards \& Midgley 1976) and spermatogenesis (Nieschlag et al. 1999) respectively.

Sprengel et al. (1990) cloned the cDNA of FSHR from rat testicular cells. Later, the mapping of FSHR gene on the chromosome number $2 \mathrm{p} 21$ in human was reported (Rousseau-Merck et al. 1993). The FSHR gene is $192 \mathrm{~kb}$ in size and comprises ten exons and nine introns (Gromoll et al. 1994). The first nine exons encode the
$\mathrm{N}$-terminal part of the extracellular domain (ECD). Exon 10 is large and encodes the C-terminal part of the ECD (hinge region), the transmembrane domain (TMD), and the intracellular domain (ICD) of the receptor. The TMD comprises seven $\boldsymbol{\alpha}$-helices, interconnected through three extracellular (ELs) and three intracellular loops (ILs). The ICD is predominantly coupled to a Gs protein that is responsible for initiating a cascade of intracellular events leading to specific biological effects of the ligand. The X-ray crystal structures of FSH complexed with the ECD of FSHR (Fan \& Hendrickson 2005, Jiang et al. 2012) have immensely contributed to understanding the interaction of FSH with its receptor at the molecular level. However, it does not provide information on ligandinduced activation of the receptor leading to steroidogenesis.

Fsh $\beta$ gene (Kumar et al. 1997) and Fshr gene (Dierich et al. 1998) knockout female mice were found to be infertile with thin uteri and streak ovaries. But in both cases the male mice were fertile, although there was a decrease in testicular size and partial spermatogenic failure. These observations clearly indicate that FSH is absolutely essential for female fertility. In recent years, naturally occurring mutations in the $F S H$ and $F S H R$ genes have been reported. In vitro functional characterization 
of these mutants has provided valuable information with respect to genotype-phenotype correlation in the case of both FSH and FSHR. Studies of FSHR mutants also provide an opportunity to understand the extracellular and intracellular events, such as hormone binding, signal transduction, and receptor trafficking, in response to FSH action. The FSHR gene is highly polymorphic in nature and three single nucleotide polymorphisms (SNPs) at positions $-29,307$, and 680 have been extensively studied by various investigators using different ethnic populations both in males and females. Currently, FSH is used as a therapeutic in reproductive medicine, and published data on SNPs of FSHR has provided a new dimension with an emphasis on 'pharmacogenetics of FSH action' (Laan et al. 2012). Alternatively spliced variants of the FSHR gene have been reported and some of them affect fertility, mainly in females (Song et al. 2002, Gerasimova et al. 2010).

Our group is working on understanding the structurefunction relationship of FSHR and one of the approaches employed toward this is studying the naturally occurring mutations, SNPs, and spliced variants of FSHR in women enrolled in IVF and infertility clinics. In the present review, we have made an attempt to provide an update on FSHR gene mutations and their effect on hormone-receptor interaction and signal transduction. We have also reviewed the usefulness of studying FSHR polymorphisms in developing a molecular marker for predicting ovarian response in women who are treated with FSH. Toward the end, the available information on the spliced variants of FSHR is also included.

\section{Naturally occurring mutations of the FSHR gene}

The presence of naturally occurring inactivating/ activating mutations in the FSHR gene has been found to be a rare phenomenon when compared with the occurrence of mutations in the $L H R$ and TSHR genes (Dufau et al. 1995). Studies suggest that the probable reason for the rare occurrence of the FSHR gene mutations could be due to the virtual absence of disease characterized by the deficiency or hypersecretion of FSH. Moreover, the FSHR mutations leading to severe forms of phenotype causing infertility are not inherited by the next generation. Therefore, screening of subjects with the phenotypes related to lack or hypersecretion of the FSH might remain unnoticed. The loss-of-function mutations in FSHR have been found in women with ovarian dysgenesis (ODG), primary amenorrhea, and secondary amenorrhea. Such mutations are also reported in men with small testes and impaired spermatogenesis (Table 1). On the other hand, gainof-function mutations have been identified in women with ovarian hyperstimulation syndrome (OHSS) and in a single case of a hypophysectomized man (Table 2). The positions of the mutations reported so far in the ECD and TMD of FSHR have been shown in Fig. 1. For depicting the mutations in the ECD, the X-ray crystal structure of FSH complexed with ECD-FSHR (Jiang et al. 2012 ) is used. Whereas, for depicting the mutations in the TMD, the homology model generated for TMD-FSHR based on the rhodopsin receptor structure is used (Okada et al. 2004).

FSH action on its target cells involves initial binding of hormone to the receptor followed by signal transduction. These two events of hormone binding and signal transduction are generally studied by in vitro experiments while characterizing the naturally occurring mutations of FSHR.

\section{Inactivating mutations}

Identification of an inactivating mutation in the FSHR gene was first reported by Aittomäki et al. (1995) in women with ODG. In Finland, a large genetic survey of women with ODG was carried out. ODG is characterized by elevated gonadotropin levels and primary amenorrhea with normal karyotype. By genetic analysis, the locus segregating the disease was mapped on chromosome number $2 p$, which corresponds to the locus for both FSHR and LHR. As the males in these families were unaffected and their androgen levels were found to be normal, the mutation screening for only the FSHR gene was carried out. The observed mutation was at position 189 substituting Ala to Val in the ECD of FSHR. This mutation was found to be homozygous in affected women. In vitro functional studies with the mutant receptor expressed in MSC-1 cells showed reduced ligand-binding ability probably due to reduced expression on the cell membrane. However, the ligandbinding affinity was not affected. FSH-induced cAMP was abolished in the mutant receptor when compared with the WT receptor. Amino acids from 189 to 193 (AFNGT) in FSHR are conserved across all the glycoprotein hormone receptors and also across all the species. $N^{191}$ is the proposed glycosylation site and the mutations at position 189 may have an effect on glycosylation and probably on trafficking of mature receptor onto the membrane (Davis et al. 1995).

Although this mutation in a homozygous condition has impaired fertility in females, the affected male siblings homozygous for this mutation showed a variable degree of spermatogenic failure. None of the five men investigated was found to be azoospermic. Only one was infertile, while two of them had fathered children (Tapanainen et al. 1997). The phenotype observed in women and men was similar to the one shown by Fshr knockout female and male mice respectively. Another mutation in the 'AFNGT' motif (Asn ${ }^{191} \mathrm{Ile}$ ) was reported in a healthy woman in a heterozygous condition (Gromoll et al. 1996). In vitro studies with this mutation showed impairment in $\mathrm{FSH}$-induced cAMP production and this defect could also be due to lack of glycosylation, 
Table 1 Inactivating mutations of FSHR in men and women: phenotype of the affected individual and findings from in vitro functional studies with mutants when compared with WT receptor.

\begin{tabular}{|c|c|c|c|c|c|c|c|}
\hline \multirow[b]{2}{*}{ S. no. } & \multirow[b]{2}{*}{$\begin{array}{l}\text { Nucleotide change } \\
\text { (exon number) }\end{array}$} & \multirow[b]{2}{*}{$\begin{array}{l}\text { Amino acid } \\
\text { change (region) }\end{array}$} & \multirow[b]{2}{*}{ Phenotype of subjects } & \multicolumn{3}{|c|}{ Effect of mutation/s on (in vitro analysis) } & \multirow[b]{2}{*}{ References } \\
\hline & & & & $\begin{array}{l}\text { Cell surface } \\
\text { expression of } \\
\text { FSHR }\end{array}$ & FSH binding & $\begin{array}{l}\text { FSH-induced } \\
\text { CAMP }\end{array}$ & \\
\hline \multirow[t]{2}{*}{1} & c.566C > T (exon 7) & $\begin{array}{l}\text { p.Ala }{ }^{189} \mathrm{Val} \\
(\mathrm{ECD})\end{array}$ & $\begin{array}{l}\text { Hypergonadotropic } \\
\text { ovarian dysgenesis }\end{array}$ & Affected & Decreased & Decreased & $\begin{array}{l}\text { Aittomäki et al. } \\
\text { (1995) }\end{array}$ \\
\hline & Homozygous mutation & & $\begin{array}{l}\text { Variable degrees of } \\
\text { spermatogenic failure }\end{array}$ & & & & $\begin{array}{l}\text { Tapanainen } \\
\text { et al. (1997) }\end{array}$ \\
\hline \multirow[t]{2}{*}{2} & c. $573 \mathrm{~A}>\mathrm{T}($ exon 7$)$ & $\begin{array}{l}\text { p.Asn }{ }^{191} \text { Ile } \\
\text { (ECD) }\end{array}$ & $\begin{array}{l}\text { Fertile woman with normal } \\
\text { ovarian function }\end{array}$ & ND & ND & Abolished & $\begin{array}{l}\text { Gromoll et al. } \\
\quad(1996)\end{array}$ \\
\hline & Heterozygous mutation & & & & & & $\begin{array}{l}\text { Gromoll et al. } \\
(2002)\end{array}$ \\
\hline 3 & c.662T > G (exon 8) & $\begin{array}{l}\text { p. Val }{ }^{221} \text { Gly } \\
\text { (ECD) }\end{array}$ & Primary amenorrhea & ND & ND & ND & $\begin{array}{l}\text { Nakamura } \\
\text { et al. (2008) }\end{array}$ \\
\hline \multirow[t]{2}{*}{4} & $\begin{array}{l}\text { Heterozygous mutation } \\
\text { c. } 1043 \mathrm{C}>\mathrm{G} \text { (exon 10) }\end{array}$ & $\begin{array}{l}\text { p.Pro }{ }^{348} \mathrm{Arg} \\
\text { (ECD hinge } \\
\text { region) }\end{array}$ & $\begin{array}{l}\text { Primary amenorrhea with } \\
\text { increased serum FSH } \\
\text { levels }\end{array}$ & ND & Abolished & Abolished & $\begin{array}{l}\text { Allen et al. } \\
\quad(2003)\end{array}$ \\
\hline & $\begin{array}{l}\text { Hemizygous mutation } \\
\text { with inherited/de } \\
\text { novo microdeletion } \\
\text { or de novo gene } \\
\text { conversion }\end{array}$ & & & & & & \\
\hline \multirow[t]{3}{*}{5} & c. $479 \mathrm{C}>\mathrm{T}$ (exon 6) & $\begin{array}{l}\text { p.lle }{ }^{160} T h r \\
\text { (ECD) }\end{array}$ & $\begin{array}{l}\text { Secondary amenorrhea } \\
\text { with increased serum } \\
\text { FSH levels }\end{array}$ & Affected & Decreased & Decreased & $\begin{array}{l}\text { Beau et al. } \\
\quad(1998)\end{array}$ \\
\hline & c.1717C>T (exon 10) & $\begin{array}{l}\text { p.Arg } \\
\text { (IL3) }\end{array}$ & & ND & Similar & Decreased & \\
\hline & $\begin{array}{l}\text { Compound hetero- } \\
\text { zygous carrier of } \\
\text { both mutations }\end{array}$ & & & & & & \\
\hline \multirow[t]{3}{*}{6} & c. $671 \mathrm{~A}>\mathrm{T}($ exon 7) & $\begin{array}{l}\text { p.Asp }{ }^{224} \mathrm{Val} \\
(\mathrm{ECD})\end{array}$ & $\begin{array}{l}\text { Primary amenorrhea with } \\
\text { increased serum FSH } \\
\text { levels }\end{array}$ & Affected & Decreased & Abolished & $\begin{array}{l}\text { Touraine et al. } \\
\text { (1999) }\end{array}$ \\
\hline & c.1801C > G (exon 10) & $\begin{array}{l}\text { p.Leu }{ }^{601} \text { Val } \\
(\text { EL3) }\end{array}$ & & ND & Similar & Decreased & \\
\hline & $\begin{array}{l}\text { Compound hetero- } \\
\text { zygous carrier of } \\
\text { both mutations }\end{array}$ & & & & & & \\
\hline \multirow[t]{3}{*}{7} & c.566C > T (exon 7) & $\begin{array}{l}\text { p.Ala }{ }^{189} \mathrm{Val} \\
(\mathrm{ECD})\end{array}$ & $\begin{array}{l}\text { Primary amenorrhea with } \\
\text { increased serum FSH } \\
\text { levels }\end{array}$ & Affected & Decreased & Abolished & $\begin{array}{l}\text { Doherty et al. } \\
(2002)\end{array}$ \\
\hline & c.1255G > A (exon 10) & $\begin{array}{l}\text { p. Ala }{ }^{419} \mathrm{Thr} \\
\text { (TMD } \\
\text { helix 2) }\end{array}$ & & ND & Similar & Abolished & \\
\hline & $\begin{array}{l}\text { Compound hetero- } \\
\text { zygous carrier of } \\
\text { both mutations }\end{array}$ & & & & & & \\
\hline 8 & c. $1555 \mathrm{C}>\mathrm{A}$ (exon 10) & $\begin{array}{l}\text { p.Pro }{ }^{519} \mathrm{Thr} \\
(\mathrm{EL} 2)\end{array}$ & $\begin{array}{l}\text { Primary ovarian failure } \\
\text { with FSH levels }\end{array}$ & Affected & Minimal & Abolished & $\begin{array}{l}\text { Meduri et al. } \\
\quad(2003)\end{array}$ \\
\hline 9 & $\begin{array}{l}\text { Homozygous mutation } \\
\text { c. } 1231 \mathrm{~A}>\mathrm{T}(\text { exon } 10)\end{array}$ & $\begin{array}{l}\text { p.lle }{ }^{411} \text { Asn } \\
(\mathrm{TMD} \\
\text { helix 2) }\end{array}$ & PCOS & ND & ND & Similar & $\begin{array}{l}\text { Orio et al. } \\
\quad(2006)\end{array}$ \\
\hline \multirow[t]{2}{*}{10} & $\begin{array}{l}\text { Heterozygous mutation } \\
\text { c. } 1760 \mathrm{C}>\mathrm{A} \text { (exon } 10)\end{array}$ & $\begin{array}{l}\text { p.Pro }{ }^{587} \mathrm{His} \\
\text { (TMD } \\
\text { helix 6) }\end{array}$ & Primary amenorrhea & ND & ND & Abolished & $\begin{array}{l}\text { Kuechler et al. } \\
\text { (2010) }\end{array}$ \\
\hline & $\begin{array}{l}\text { Mutation on single } \\
\text { allele with } \\
\text { unbalanced } \\
\text { translocation }\end{array}$ & & & & & & \\
\hline \multirow[t]{2}{*}{11} & c. $1723 \mathrm{C}>\mathrm{T}($ exon 10) & $\begin{array}{l}\text { p.Ala }{ }^{575} \mathrm{Val} \\
\text { (TMD } \\
\text { helix 6) }\end{array}$ & $\begin{array}{l}\text { Primary amenorrhea with } \\
\text { hypergonadotropic } \\
\text { hypogonadism }\end{array}$ & ND & ND & ND & $\begin{array}{l}\text { Achrekar et al. } \\
\quad(2010)\end{array}$ \\
\hline & Homozygous mutation & & & & & & \\
\hline
\end{tabular}

ECD, extracellular domain; EL, extracellular loops; IL, intracellular loops; ND, not determined; TMD, transmembrane domain. 


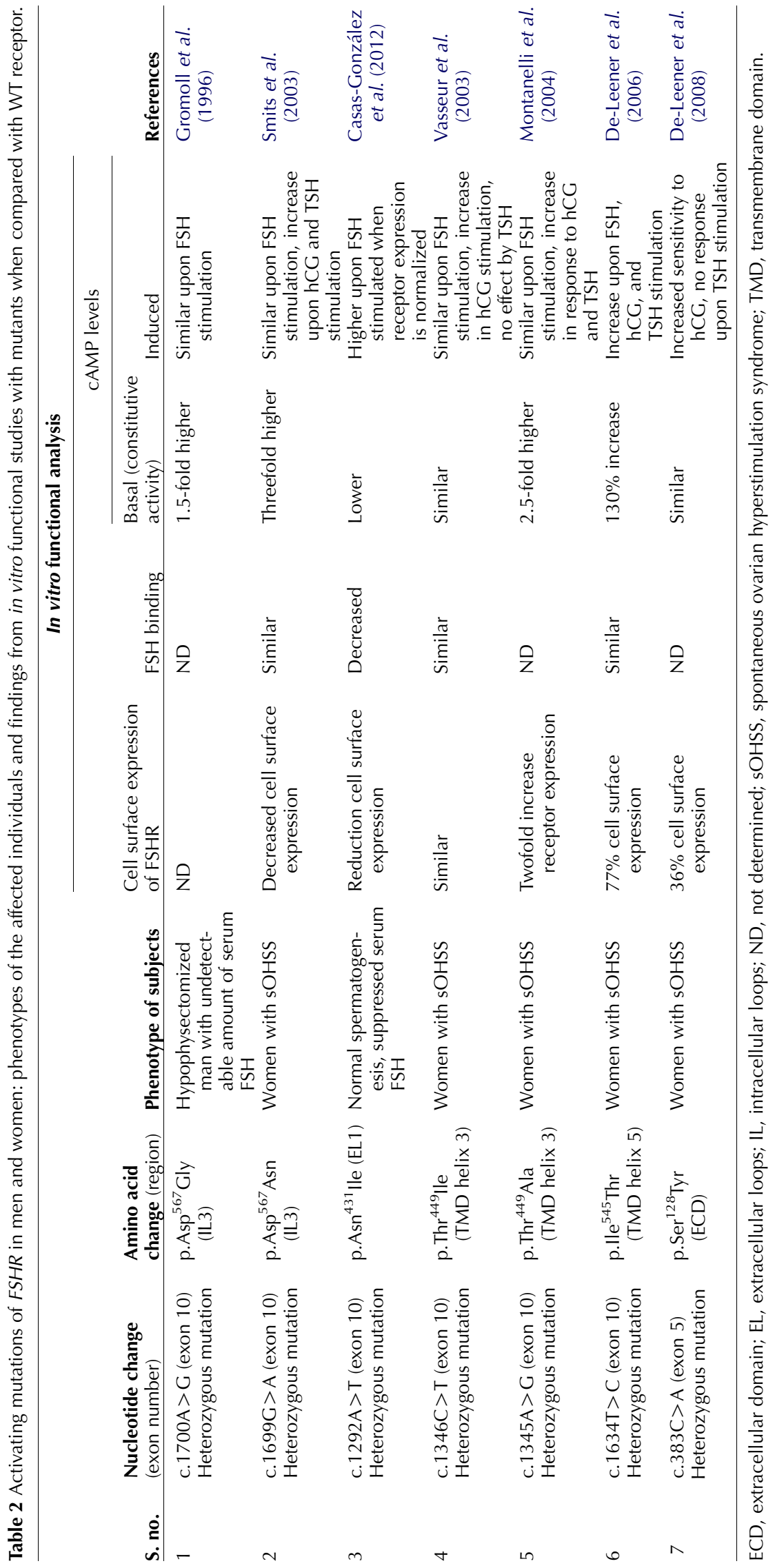




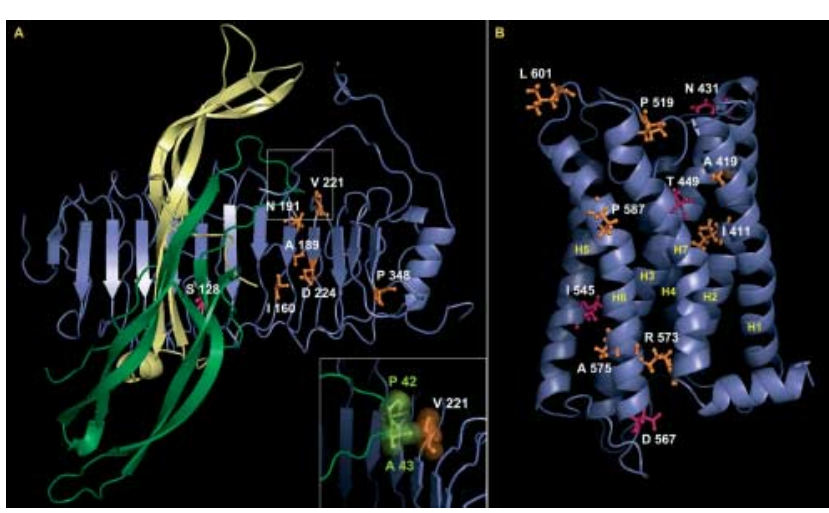

Figure 1 Positions of naturally occurring activating and inactivating mutations in FSHR (A) X-ray crystal structure of human FSH complexed with ECD of human FSHR (PDB ID: 4ay9; Jiang et al. (2012)). $\alpha$ - and $\beta$-subunits of FSH are shown in yellow and green color respectively. ECD of FSHR (in slate blue) shows the presence of leucine-rich repeats. Inset shows hydrophobic interaction of $\mathrm{V}^{221}$ of FSHR with $\mathrm{P}^{42}$ and $\mathrm{A}^{43}$ of $\beta$-subunit of FSH. (B) Homology model of TMD of FSHR constructed based on the crystal structure of bovine rhodopsin receptor (PDB ID: 1U19; Okada et al. 2004). $\mathrm{H} 1-\mathrm{H} 7$ are the helices that are interconnected by extracellular and intracellular loops. In both A and B, amino acids shown in orange and red correspond to inactivating and activating mutations of FSHR respectively.

resulting in a poor surface expression of the receptor (Gromoll et al. 2002). Recently, it has been reported that the 'AFNGT' motif plays an important role in maintaining the structural integrity of the receptor (Casas-González et al. 2012). In spite of the presence of mutation at position 191, this woman became pregnant, suggesting that the heterozygous mutations of FSHR do not affect functioning of the receptor (Gromoll et al. 1996).

Recently, a heterozygous mutation at $\mathrm{Val}^{221} \mathrm{Gly}$ position in the ECD of FSHR has been identified in women with primary amenorrhea (Nakamura et al. 2008). Interestingly, this woman responded to human menopausal gonadotropin (hMG) treatment. In vitro functional characterization of this mutant has not been reported so far. X-ray crystal structural of FSH complexed with the ECD of FSHR suggests that Val ${ }^{221}$ of FSHR is present at the hormone binding site and is in close proximity $(<5 \AA)$ with $\mathrm{P}^{42}$ and $\mathrm{A}^{43}$ of $\beta$-subunit of $\mathrm{FSH}$ (Fig. 1). This mutation may be affecting the hormone binding affinity, and the increased ligand concentration (hMG used in this case) is possibly required for receptor activation. On the other hand, the mutation at Pro ${ }^{348} \mathrm{Arg}$ from the hinge region of the ECD was detected in a woman with primary amenorrhea. Functional analysis revealed that this mutation abolished both binding and signaling of the receptor (Allen et al. 2003). As in both the above-mentioned studies the level of mature receptor expression on plasma membrane was not analyzed, the effect of the mutations on receptor conformation and trafficking cannot be assessed.

There are three different cases of the presence of compound heterozygous mutations reported in different women. In a woman with secondary amenorrhea, mutations at $1 \mathrm{le}^{160} \mathrm{Thr}$ and $\mathrm{Arg}^{573} \mathrm{Cys}$ positions were detected. The other two cases were of primary amenorrhea where the mutation reported was at $\mathrm{Asp}^{224} \mathrm{Val}$, Leu ${ }^{601} \mathrm{Val}, \mathrm{Ala}{ }^{189} \mathrm{Val}$ and Ala ${ }^{419}$ Thr. Both these women developed high plasma gonadotropin levels, contrasting with normal-sized ovaries and the presence of antral follicles. Functional studies revealed that mutations located in the ECD affect receptor trafficking, thereby affecting ligand binding and subsequent signaling, whereas mutations at $\mathrm{Arg}^{573} \mathrm{Cys}$, Leu ${ }^{601} \mathrm{Val}$, and Ala ${ }^{419} \mathrm{Thr}$ did not impact greatly on the ligand-binding ability of the receptor but did, however, show reduced cAMP production (Beau et al. 1998, Touraine et al. 1999, Doherty et al. 2002). But, when $\mathrm{Arg}^{573}$ was replaced by Ala, the plasma membrane expression was observed to be severely affected, suggesting that the nature of amino acid substitution and location of the mutation are important and are observed to be independent determinants of FSHR function (Zarinan et al. 2010).

Meduri et al. (2003) reported a novel mutation in the EL2 of FSHR at the position Pro ${ }^{519}$ Thr. This mutation has been observed in a homozygous condition in women with primary amenorrhea. Histological studies revealed a markedly enhanced number of $(24.2 \pm 4.6)$ primary follicles in the small ovaries. This mutation completely abolished the ligand binding and CAMP production in vitro, due to the defect in the trafficking of the receptor. Therefore, it can be concluded that Pro ${ }^{519}$ is probably a prerequisite for the FSHR trafficking and receptor function. Thus, along with ECD, ELs also seem to play an important role in ligand binding and receptor trafficking.

Apart from inactivating mutations identified in the ECD, a number of mutations in the helices of the TMD have also been reported so far. A mutation at $\| e^{411}$ Asn position was detected in women with polycystic ovary syndrome (PCOS; Orio et al. 2006). On the other hand, the mutations at Pro ${ }^{587} \mathrm{His}$ and $\mathrm{Ala}^{575} \mathrm{Val}$ were observed to lead to more adverse phenotypes such as primary amenorrhea (Achrekar et al. 2010, Kuechler et al. 2010). However, in vitro studies on the effect of the mutations in TMD on receptor trafficking have not yet been reported so far.

Genotype-phenotype association studies and in vitro functional characterization of these inactivating mutations of FSHR have provided valuable information about the contribution of the mutated residues and the corresponding region in hormone receptor interaction and signal transduction. In case of certain mutations, the defect is at the level of maturation of the receptor which is responsible for its trafficking onto the cell surface. Recently, efforts have been made to rescue the trafficking defective mutation to the cell surface using a pharmacoperone (Org41841) by Janovick et al. (2009). This drug was observed to bind to the FSHR at a site other than the $\mathrm{FSH}$ binding site and it increased the membrane 
expression of mutant FSHR $\left(A^{189} \mathrm{~V}\right)$ associated with misrouting and endoplasmic reticulum retention. Such studies need to be undertaken in future, which will form the basis for developing treatment modalities in some cases of reproductive abnormalities due to non-functioning of the receptor.

\section{Activating mutations}

Activating or gain-of-function mutations in the FSHR gene have been reported in both men and women. However, the number of cases reported is few when compared with the incidences and severity of the phenotype reported with activating mutations of the LHR gene (Meehan \& Narayan 2007).

The first activating mutation was reported in a hypophysectomized, hypogonadotropic man (Gromoll et al. 1996). Although the serum gonadotropin levels were undetectable, he had normal testis volume and semen parameters. He had also fathered three children with testosterone treatment. The mutation was identified at $\mathrm{Asp}^{567}$ Gly position in the IL3 of FSHR. This mutant exhibited ligand-independent constitutive activity when tested in vitro. It was reported that $\mathrm{Asp}^{567}$ is conserved across other glycoprotein receptors. The mutation in the corresponding residues in TSHR and LHR has also been reported. A mutation at Asp ${ }^{619} \mathrm{Gly}$ in TSHR was reported in cases with thyroid hyperfunctioning adenoma (Russo et al. 1996) and $\mathrm{Asp}^{564}$ Gly in LHR was reported in cases of pseudoprecocious puberty (Laue et al. 1995). Interestingly, the first activating mutation in a female was identified at the same residue (567) of FSHR. The $\mathrm{Asp}^{567}$ was found to be mutated to Asn in a woman with spontaneous OHSS (sOHSS). The mutant receptor displayed threefold higher constitutive activity when studied in vitro and also responded to hCG and TSH treatment (Smits et al. 2003). Apart from Asp ${ }^{567}$ Gly mutation, there is another activating mutation at $\mathrm{Asn}^{431} \mathrm{lle}$ reported in an asymptomatic man (CasasGonzález et al. 2012). In vitro experiments demonstrated decreased cell surface expression of the mutant receptor. Further, the agonist-induced desensitization and internalization were found to be markedly altered.

All the activating mutations reported in women till date are associated with sOHSS. There are two cases of sOHSS where the $\mathrm{Thr}^{449}$ in the TMD was substituted. In one case, the mutation was at $\mathrm{Thr}^{449}$ Ile (Vasseur et al. 2003) and in the second case it was $\mathrm{Thr}^{449} \mathrm{Ala}$ (Montanelli et al. 2004). Both the mutations were heterozygous in condition and displayed decreased hormone binding specificity of the receptor as these mutant receptors also responded to hCG. Substitution of Thr to Ala was observed to give constitutive activity to the receptor and was also observed to be nonspecifically responding to both hCG and TSH, whereas in the case of mutation at $\mathrm{Thr}^{449} \mathrm{lle}$, no constitutive activity was observed and the mutant receptor was not responding to $\mathrm{TSH}$.
The mutation at $1 \mathrm{e}^{545} \mathrm{Thr}$, also from the TMD, was detected in a woman with sOHSS. When tested, this mutation was found to cause cross-sensitivity of the receptor to both hCG and TSH together. The mutant receptor was also observed to be constitutively active. It was interesting to note that the symptoms of sOHSS were observed in this patient in the first trimester of pregnancy with normal hCG levels. The examination of an other seven women with sOHSS and high hCG or TSH levels indicated the presence of normal FSHR genotype. This suggests that, for these seven patients, sOHSS results from the natural promiscuous stimulation of WT FSHR by very high levels of hCG or TSH (De-Leener et al. 2006). It is worth noting that most of the germ line mutations in FSHR causing sOHSS were identified in the TMD (remote to the hormone binding site) of the FSHR. These mutations were observed to cause a non-specific response to hCG and TSH while displaying constitutive activity.

So far, there is only one report on an activating mutation (Ser ${ }^{128} \mathrm{Tyr}$ ) from the ECD observed in a case of sOHSS (De-Leener et al. 2008). In contrast to the other mutations, this mutation in the ECD did not show any constitutive activity but exhibited higher affinity and sensitivity toward hCG but not to TSH. Subsequently, the extensive site-directed mutagenesis study at position 128 demonstrated that the increase in the sensitivity to hCG selectively is not a consequence of the loss of serine residue, as some substitutions were found to be neutral (Ser to $\mathrm{Ala} / \mathrm{His}$ ), whereas some substitutions were observed to be sensitive to both hCG and TSH (e.g. Ser to lle/Val).

In general, it is observed that the gain-of-function mutations in the FSHR gene can cause a phenotype even when present in the heterozygous condition with dominant inheritance whereas the loss-of-function mutations are mostly transmitted recessively and give a phenotype only when present in the homozygous or compound heterozygous condition. Although studies were carried out to detect mutation in diseases such as ovarian tumors, megalotestes, precocious puberty, and twin pregnancies, no change in the FSHR gene was observed. This suggests that the phenotypes associated with the activating mutations of FSHR are still unclear in both men and women.

\section{SNPs of the FSHR gene}

Various SNPs in the coding and non-coding region ( $>1300$ SNPs) of the FSHR gene have been identified in diverse populations. Of the total of eight polymorphisms present in the coding region, six are non-symptomatic and the other two polymorphisms present at position p.Thr ${ }^{307} \mathrm{Ala}$ (rs6165) and p.Asn ${ }^{680} \mathrm{Ser}$ (rs6166) are most extensively studied to assess the response of the receptor to FSH stimulation. The polymorphism at position 307 is located in the hinge region of the ECD whereas the polymorphism at position 680 is present in the ICD of the 
receptor. As both the polymorphisms are present in the same exon 10, they are observed to be in strong linkage disequilibrium. As the frequency distribution in various populations revealed that the $\mathrm{Thr}^{307}-\mathrm{Asn}^{680}$ and $\mathrm{Ala}^{307}$ $\mathrm{Ser}^{680}$ isoforms are predominant, most of the association studies focused on the polymorphism at position 680 alone. These two isoforms were believed to be present as potential glycosylation/phosphorylation sites of FSHR as Asn ${ }^{680}$ introduces a consensus sequence for glycosylation which in turn may play a role in receptor trafficking and $\mathrm{Ser}^{307}$ may contribute as a phosphorylation site, which might be involved in receptor turnover (Davis et al. 1995). Other than the polymorphisms in the coding region, Wunsch et al. identified the two polymorphisms at positions -29 and -114 in the $5^{\prime}$ UTR of the FSHR gene. These two polymorphisms are also linked due to their close proximity with each other. SNP in the -29 position (rs1394205) has been observed to be present in the viral E26 transformation-specific sequence (c-ETS-1) transcription factor binding site (Wunsch et al. 2005).

\section{Association of FSHR gene polymorphisms with ovarian response}

As FSH plays a central role in stimulating follicular growth, it is used for controlled ovarian stimulation during IVF protocol and for various other infertility treatments in both females and males. Although similar stimulation protocols are used in IVF, the ovarian response to exogenous FSH varies widely ranging from poor to hyper-responsive. Many parameters, such as age and diminished ovarian reserve (Klingman \& Rosenwaks 2001) and serum AMH levels (Nardo et al. 2009), have been used as a marker to predict the ovarian response. However, determining the dose of FSH to attain optimum response is one of the ongoing challenges in the field of infertility management in IVF clinics. By far, polymorphisms in the FSHR gene are most studied in relation to ovarian response in various populations and findings are summarized in Table 3.

Perez-Mayorga et al. (2000) demonstrated for the first time the association of higher serum FSH levels with the $\operatorname{Ser}^{680}$ allele in women undergoing IVF. This paper served as a real breakthrough in signifying the role of FSHR gene polymorphisms as a genetic marker to predict ovarian response. Studies on the functional characteristics of these two isoforms were reported by various investigators. The in vitro functional analysis of the $\mathrm{Thr}^{307}-\mathrm{Asn}^{680}$ and $\mathrm{Ala}^{307}-\mathrm{Ser}^{680}$ isoforms suggested that the FSH binding and cAMP production are similar for both these isoforms (Tilly et al. 1992, Minegishi et al. 1994, Simoni et al. 1999, Sudo et al. 2002). Response of these isoforms to TSH stimulation was also characterized in HEK-293 cells and was observed to be alike (Ryan et al. 2007). Therefore, the molecular mechanism by which both these polymorphisms might be altering the ovarian response is still unclear. Significantly higher basal FSH levels and lower estradiol production upon hCG stimulation were associated with $\operatorname{Ser}^{680}$ allele in studies conducted in different ethnic groups (Sudo et al. 2002, de-Castro et al. 2004, Behre et al. 2005, Greb et al. 2005). Recently, a meta-analysis carried out by Morón \& Ruiz (2010), Altmäe et al. (2011), and Yao et al. (2011) suggested that the $\operatorname{Ser}^{680}$ allele is the only promising marker available to be used in clinical setup to predict the ovarian response to FSH stimulation.

Nevertheless, in the above studies, the significant associations of Ser/Ser genotype with total amount of FSH administered, number of follicles, and mature oocytes were not observed when compared with Asn/Asn genotype alone or in combination with Asn/Ser genotype at position 680 . In a study reported by de-Castro et al. (2004), although the percent of poor responders were significantly higher in women with Ser/ Ser genotype, the other clinical parameters, such as peak $E_{2}$ levels, number of follicles and oocytes, and amount of exogenous FSH, were observed to be similar in all the three genotypes at position 680 of FSHR. Additionally, it was noted that in a systematic randomized control study, women with either Ser/Ser or Asn/Asn genotype with 150 or $225 \mathrm{IU} /$ day of $\mathrm{FSH}$ dose resulted in a similar number of follicles and retrieved oocytes, fertilization rate, and clinical pregnancy (Behre et al. 2005). Furthermore, there are reports from different ethnic origins from The Netherlands (Laven et al. 2003, Klinkert et al. 2006) and UK (Mohiyiddeen et al. 2012), which did not report any association of the polymorphism at position 680 with poor ovarian response.

On the other hand, in the study by Greb et al. (2005), the number of antral follicles was observed to be significantly greater in women with Ser/Ser genotype $(22.6 \pm 1.3)$ when compared with Asn/Asn genotype $(17.8 \pm 1.1)$. Similarly, the systematic study of subjects with ODG, poor responders, and good responders demonstrated that subjects with Ser/Ser genotype generate a significantly higher amount of estradiol and higher number of follicles and oocytes when compared with subjects with Asn/Asn genotype (Loutradis et al. 2006). Daelemans et al. (2004) also reported that women with the $\operatorname{Ser}^{680}$ allele were at risk of showing hyper-response when compared with the $\operatorname{Asn}^{680}$ allele. Similarly, our group has observed that although not significant, $50 \%$ of the subjects (three of six subjects) with p.Ser ${ }^{680} \mathrm{Ser}$ genotype developed OHSS (Achrekar et al. 2009a).

The association of polymorphism at position 307 with ovarian hyper-response was reported in an Indian population. Almost $85 \%$ of the subjects (six of seven subjects) with Ala ${ }^{307}$ Ala genotype were found to be significantly associated with iatrogenic OHSS. These subjects developed OHSS when stimulated with significantly lower amount of exogenous FSH and demonstrated significantly higher levels of estradiol before and on the day of hCG stimulation (Achrekar et al. 2009a). As mentioned earlier, Ala at 307 is linked with the Ser ${ }^{680}$ 
Table 3 Studies on association of the polymorphism in the FSHR gene with ovarian response in women undergoing the IVF program.

\begin{tabular}{|c|c|c|c|}
\hline Polymorphism & $\begin{array}{c}\text { Subjects } \\
\text { screened }(n)\end{array}$ & Outcome of the studies & Reference \\
\hline \multirow[t]{14}{*}{ p.Asn ${ }^{680}$ Ser } & 161 & $\begin{array}{l}\text { Women with Ser/Ser and Asn/Ser genotype showed significantly higher basal } \\
\text { FSH levels and required significantly higher FSH dose for ovarian stimulation } \\
\text { when compared with Asn/Asn genotype } \\
\text { Peak estradiol levels, number of follicles, and oocytes were similar in women with } \\
\text { all three genotypes }\end{array}$ & $\begin{array}{l}\text { Perez-Mayorga et al. } \\
\quad(2000)\end{array}$ \\
\hline & 58 & $\begin{array}{l}\text { Women with Ser/Ser genotype were significantly associated with increased } \\
\text { exogenous FSH and decreased estradiol levels on the day of hCG administration } \\
\text { The number of oocytes retrieved was similar in all three genotypes }\end{array}$ & Sudo et al. (2002) \\
\hline & 102 & $\begin{array}{l}\text { Ser/Ser genotype displayed significantly higher basal FSH levels and higher } \\
\text { number of IVF cycles }\end{array}$ & de-Castro et al. (2004) \\
\hline & & $\begin{array}{l}\text { The peak estradiol levels, number of follicles, and oocytes were similar in all three } \\
\text { genotypes }\end{array}$ & \\
\hline & 93 & $\begin{array}{l}\text { Women with Ser/Ser genotype required higher total FSH dose ( } 225 \mathrm{U} / \text { day) for } \\
\text { ovarian stimulation when compared with women with Asn/Asn genotype (who } \\
\text { received } 150 \mathrm{U} / \text { day) to attain similar ovarian response }\end{array}$ & Behre et al. (2005) \\
\hline & & $\begin{array}{l}\text { Basal FSH, number of follicles, oocytes, and pregnancy rate was not different } \\
\text { among Ser/Ser (150 U/day), Ser/Ser (250 U/day), and Asn/Asn (150 U/day) } \\
\text { groups }\end{array}$ & \\
\hline & 148 & $\begin{array}{l}\text { Women with Ser/Ser genotype displayed significantly higher basal FSH levels, but } \\
\text { the peak estradiol levels, exogenous FSH levels, number of follicles, and oocytes } \\
\text { were similar when compared with women with Asn/Asn and Asn/Ser genotype }\end{array}$ & Laven et al. (2003) \\
\hline & 105 & $\begin{array}{l}\text { Women with Ser/Ser genotype had implantation and pregnancy rate significantly } \\
\text { higher than women with Asn/Asn genotype }\end{array}$ & Klinkert et al. (2006) \\
\hline & 421 & $\begin{array}{l}\text { The total amount of FSH stimulated and the number of oocytes retrieved were } \\
\text { similar in all three genotypes }\end{array}$ & Mohiyiddeen et al. (2012) \\
\hline & 64 & $\begin{array}{l}\text { Women with Ser/Ser genotype were associated with higher ovarian threshold to } \\
\text { FSH, decreased negative feedback of luteal secretion, longer menstrual cycles } \\
\text { but displayed significantly higher number of antral follicles }\end{array}$ & Greb et al. (2005) \\
\hline & & $\begin{array}{l}\text { Peak estradiol levels, inhibin B, and growth velocities of dominant follicles were } \\
\text { not significantly different among the three genotypes }\end{array}$ & \\
\hline & 79 & $\begin{array}{l}\text { Women with Asn/Ser genotype generate a significantly higher amount of estradiol } \\
\text { and higher number of follicles and oocytes when compared with women with } \\
\text { Ser/Ser and Asn/Asn genotype }\end{array}$ & Loutradis et al. (2006) \\
\hline & 37 & $\begin{array}{l}\text { Ser }^{680} \text { allele present more risk of giving iatrogenic OHSS when compared with } \\
\text { Asn }^{680} \text { allele, but the Asn }{ }^{680} \text { allele was significantly associated with severity of } \\
\text { iatrogenic OHSS }\end{array}$ & Daelemans et al. (2004) \\
\hline & 427 & $\begin{array}{l}\text { Women with Ser/Ser genotype were more likely to have hyper-response than } \\
\text { women with Asn/Asn genotype }\end{array}$ & Boudjenah et al. (2012) \\
\hline \multirow[t]{2}{*}{ p.Thr ${ }^{307}$ Ala } & 50 & $\begin{array}{l}\text { Women with } \mathrm{Ala}^{307} \text { Ala genotype were significantly associated with lower dose of } \\
\text { exogenous FSH, higher estradiol levels before and on the day of hCG } \\
\text { stimulation }\end{array}$ & Achrekar et al. (2009a) \\
\hline & & $85 \%$ of the women with Ala/Ala genotype developed OHSS & \\
\hline \multirow[t]{3}{*}{ g.G $>$ A -29} & 202 & $\begin{array}{l}\text { Basal FSH and estradiol levels were not significantly different among the three } \\
\text { genotypes at position }-29\end{array}$ & Wunsch et al. (2005) \\
\hline & 50 & $\begin{array}{l}\text { Women with AA genotype displayed lower estradiol levels, number of follicles } \\
\text { and oocytes, and higher total amount of exogenous FSH administered when } \\
\text { compared with women with GG genotype }\end{array}$ & Achrekar et al. (2009b) \\
\hline & 100 & $\begin{array}{l}\text { The level of FSHR expression at transcript and protein levels was significantly } \\
\text { reduced in women with AA genotype when compared with GG genotype }\end{array}$ & Desai et al. (2011) \\
\hline
\end{tabular}

allele. Thus, it is more likely that the Ser ${ }^{680}$ allele along with the $\mathrm{Ala}^{307}$ allele may be associated with hyperresponse to $\mathrm{FSH}$ stimulation.

The rate of pregnancy in an IVF cycle is very important as it is considered as a measure to determine the IVF outcome. Klinkert et al. (2006) reported that the Ser ${ }^{680}$ allele is more likely to give a higher pregnancy rate when compared with the Asn ${ }^{680}$ allele. Recently, a genomewide analysis carried out by Boudjenah et al. (2012) reported that women with Ser/Ser genotype were more likely to have a high response than women with Asn/Asn genotype at position 680 (24 vs $12 \%$ respectively, $P=0.013)$. These observations suggest that there is a lack of consistency in the outcome of these association studies and there is a need for clarity in defining the poor ovarian response. Various attempts have been made to study the impact of the polymorphism at position 680 on FSHR activity using GCs. GCs obtained from women with three different genotypes at position 680 were cultured for a short time ( $\sim 6-7$ days $)$ and were used to study the response of FSH stimulation. Results revealed that the amount of cAMP production and estrogen and progesterone synthesis was similar in GCs obtained from all three genotypes at position 680. Although the basal estradiol levels in GCs with Ser/Ser genotype were significantly lower, the estrogen production upon FSH 
stimulation did not differ significantly between the three genotypes, suggesting that the probable contribution of polymorphism at position 680 needs further investigation in long-term GC culture system (Nordhoff et al. 2011, Zalewski et al. 2013).

The level of FSHR expression also has an impact on the FSH action. Moreover, the reduced expression of FSHR on GCs has been shown to be associated with poor ovarian response (Cai et al. 2007). The polymorphism at position -29 of the $5^{\prime}$ UTR in the FSHR gene has been studied with respect to its effect on receptor expression as this polymorphism may modulate the cETS-1 transcription factor binding site. In vitro analysis carried out in $\mathrm{CHO}$ cells demonstrated that the $\mathrm{A}^{-29}$ allele expressed a significantly lower level of luciferase activity when compared with the $\mathrm{G}^{-29}$ allele of the FSHR gene (Nakayama et al. 2006). Despite the fact that Wunsch et al. (2005) did not observe any association of the polymorphism at position -29 with ovarian response, the clinical parameters considered in this study were limited (basal FSH levels and $E_{2}$ levels). Recently, we observed that subjects with AA genotype were significantly associated with a reduced number of follicles and retrieved oocytes when compared with subjects with GG genotype. The amount of FSH required for optimum response was also significantly higher in subjects with AA genotype when compared with GG genotype. Almost $66.67 \%$ (odds ratio $8.154 ; 95 \% \mathrm{Cl} 2.79$ to 23.77; $P<0.0001)$ subjects with AA genotype were poor ovarian responders (Fig. 2; Achrekar et al. 2009b, Desai et al. 2011, 2013). Further, using GCs obtained from women undergoing IVF, we observed that subjects with AA genotype expressed significantly reduced FSHR expression both at transcript and protein level when compared with GG genotype (Desai et al. 2011). This study provides the experimental evidence to suggest that reduced receptor expression observed in subjects with AA genotype could be the probable reason for the poor ovarian response to FSH stimulation observed in them. However, a greater number of subjects from various ethnic populations needs to be analyzed to assess the usefulness of screening this polymorphism, which could be used as a biomarker to predict poor ovarian response.

\section{Association of FSHR gene polymorphisms with PCOS, premature ovarian failure, and amenorrhea}

PCOS represents a clinical condition distinguished by impaired menstrual cycle and formation of multiple cysts in the ovary. In these subjects, LH:FSH ratio is generally increased and there is excessive production of androgen (Goodarzi et al. 2011). So far, a number of polymorphisms has been studied in various candidate genes to predict the risk of developing PCOS. A meta-analysis across the eight studies suggested that the Asp ${ }^{680}$ allele was associated with lower risk and the $\mathrm{Ala}^{307}-\mathrm{Ser}^{680}$
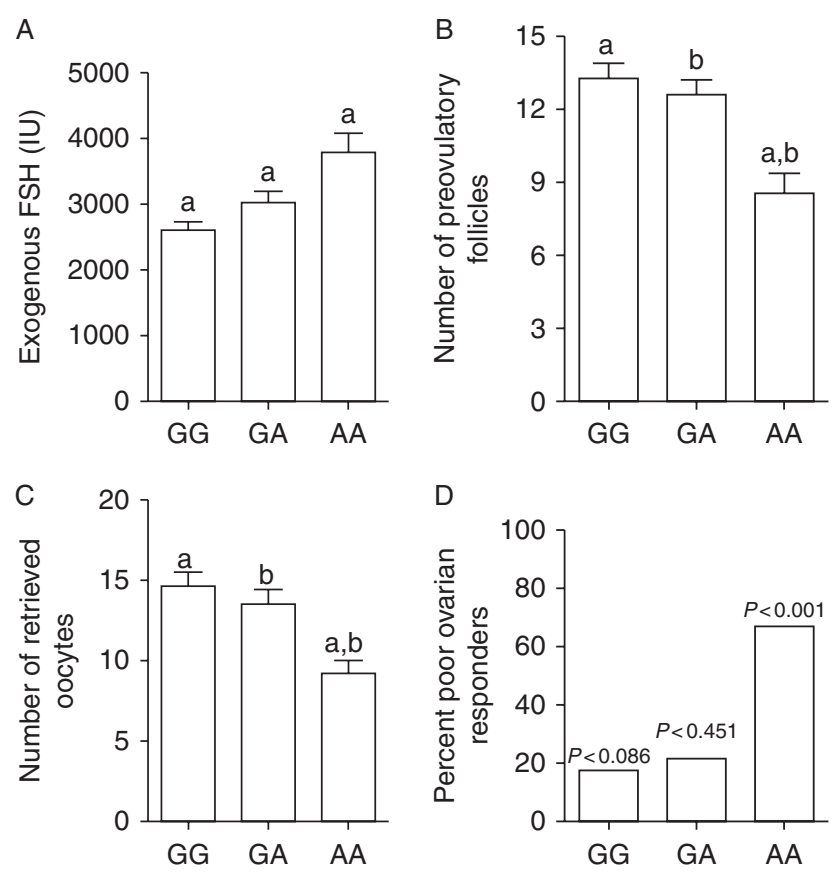

Figure 2 Association of AA genotype at position - 29 of the FSHR gene with poor ovarian response (A, B, C and D). Amount of (recombinant or urinary) exogenous $\mathrm{FSH}$ administered during controlled ovarian hyperstimulation, number of preovulatory follicles, number of retrieved oocytes, and percent poor ovarian responders respectively in women $(n=150)$ with different genotypes who are undergoing an IVF protocol (Achrekar et al. 2009b, Desai et al. 2011, 2013). The same letter (a or b) indicates statistically significant difference at $P \leq 0.05$ among different genotypes.

genotype was associated with an increased risk of developing PCOS (Du et al. 2010).

Generally, treatment of infertility in cases with PCOS is based on increasing the level of FSH either by antagonizing the effect of estrogen by clomiphene citrate (CC) or by administrating recombinant $\mathrm{FSH}(\mathrm{rFSH})$. Recently, it was observed that subjects with Ser/Ser genotype at position 680 exhibited high resistance to CC treatment but showed the most favorable response to $\mathrm{rFSH}$ stimulation (Overbeek et al. 2009). Likewise, in a study in PCOS women from Italy, Asn/Thr genotype at position 307 displayed higher response to $\mathrm{FSH}$ stimulation when compared with both the homozygous genotypes (Dolfin et al. 2011).

Premature ovarian failure (POF) is also referred to as primary ovarian insufficiency (POI) and is characterized by low levels of gonadal hormones (estrogen, inhibins) and elevated levels of $\mathrm{FSH}$ with impaired ovarian folliculogenesis. The phenotype of the FSHR knockout mice was observed to be similar as observed in POF (Dierich et al. 1998). Thus, FSHR could serve as a strong candidate gene responsible for the phenotype observed in the females with POF. Although there are no clear associations observed in FSHR gene polymorphism with POF, recently Kim et al. (2011) reported that epistasis between FSHR and CYP19A1 polymorphisms was significantly associated with POF. 
In the case of subjects with amenorrhea, an association with the Ser ${ }^{680}$ allele has been observed (Sudo et al. 2002). Recently, our group has investigated the association of polymorphisms at position $-29,307$, and 680 in women with primary and secondary amenorrhea. We observed that in the subjects with primary amenorrhea, AA genotype at position -29 was significantly associated with increased basal serum FSH levels when compared with GG and GA genotype (Achrekar et al. 2010).

\section{Association of FSHR gene polymorphisms with male infertility}

In recent years, several studies on the association of the FSHR gene polymorphisms on sperm motility, sperm counts, and testicular volume were carried out. Most of the reports showed no significant association of the polymorphisms at position -29, 307, and 680 with these parameters (Ahda et al. 2005, Pengo et al. 2006, Li et al. 2011, Lindgren et al. 2012). The recent three meta-analyses that summarized the seven original papers also suggest no association of these polymorphisms with reproductive abnormalities in men (Tüttelmann et al. 2007, Lend et al. 2010, Wu et al. 2012). However, it was interesting to note that subjects with AA genotype at position -29 showed significantly smaller mean testicular volumes when compared with subjects with GG genotype (Lend et al. 2010). Taken together, these studies from different populations suggest that FSHR genotype does not seem to have a significant impact on male reproductive physiology.

\section{Association of FSHR gene polymorphisms with gonadal cancer}

There are limited studies on FSHR gene polymorphisms in cases with ovarian or testicular cancer. Contradicting observations with respect to the association of FSHR polymorphisms with low or high risk of forming gonadal cancers have been reported. Ala $^{307} / \mathrm{Ser}^{680}$ allele alone or in combination with $\mathrm{G}^{-29} / \mathrm{T}^{-114}$ allele was observed to be associated with lower risk of developing testicular cancer (Ferlin et al. 2008). On the other hand, homozygous $\mathrm{Ala}^{307} / \mathrm{Ser}^{680}$ alleles have been associated with higher risk and recurrence of developing ovarian cancer (Ludwig et al. 2009). However, the mechanism by which these alleles could modulate the FSHR function in ovarian or testicular cancer cells is still unknown and holds a great research interest.

\section{Alternatively spliced variants of the $F S H R$ gene}

Alternatively spliced variants of the $F S H R$ gene have been identified in various species such as cattle, rat, and sheep. Alternatively spliced variants of the FSHR gene in rat and sheep have been observed to result in the soluble form of the protein or modification of the C-terminal domain of the receptor (Sairam et al. 1996, Yarney et al. 1997). In humans, alternate splicing of exon 9 in normal testicular tissue has been reported, which suggests that this spliced variant does not affect the FSHR function in testis (Gromoll et al. 1992). Deletion of exons 6 and 9 and insertion of part of intron 8 has also been identified in infertile men (Song et al. 2002). Additionally, a number of spliced variants such as del exon 2, 6, and 9 and insertion of $102 \mathrm{bp}$ of intron 8 along with the WT FSHR in the GCs obtained from women undergoing IVF has also been reported. The clinical parameters of these women suggested that deletion of exon 2 was associated with poor ovarian response whereas deletion exon 6 was associated with a high response (Gerasimova et al. 2010). In our study, in subjects undergoing IVF, we observed that out of a total of 20 subjects screened, only one subject was observed to posses insertion of a part of intron 8 (102 bps) along with the WT-FSHR (S S Desai and S D Mahale 2011, unpublished data). However, this spliced variant did not seem to affect the various clinical parameters. Therefore, screening of spliced variants in a greater number of subjects is essential to corroborate their role in ovarian response and female infertility.

\section{Summary and future perspective}

Studies reported so far clearly indicate that mutations, polymorphisms, and alternatively spliced variants in $F S H R$ have varied effects on receptor function. The overview of the phenotypes associated with genetic alterations in the FSHR and their functional characterization carried out so far has been summarized in Fig. 3. Identification of different inactivating mutations in the FSHR gene and correlating them with respective phenotypes clearly suggest that receptor function is impaired in women with such mutations, resulting in infertility. However, the affected men had no effect on their fertility. In vitro functional studies undertaken to characterize these mutants have provided valuable information in understanding FSH-FSHR interaction at the molecular level. These mutations are believed to bring about structural change in the receptor, thereby reducing the hormone binding ability or hormoneinduced signaling ability. Few of the mutations have shown any defect at the level of trafficking to the cell membrane, probably due to a defect in the maturation of the receptor (Casas-González et al. 2013). Further studies with these mutants will possibly help in understanding the events involved in post-translational modifications of FSHR, its interaction with intracellular adaptor molecules, internalization, recycling, degradation of the activated receptor, etc. In addition, generation of the corresponding mutant animal model will help in developing modalities to rescue the receptor function. Toward this, efforts have been made to use small molecules capable of restoring the receptor function 


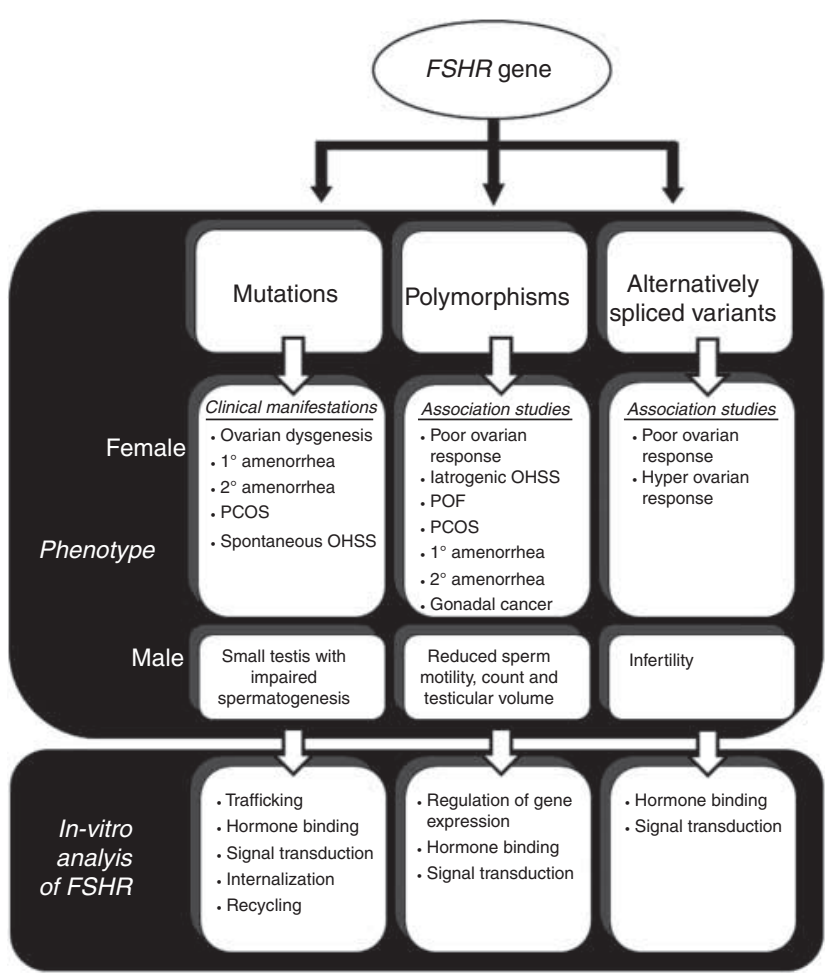

Figure 3 Schematic representation of an overview of the genetic alterations in FSHR and associated phenotypes reported so far. In vitro functional studies employed for characterizing the mutant receptor are also included.

using COS cells (Janovick et al. 2009). In the case of activating mutations of FSHR gene, the receptor activity was found to be enhanced mainly due to loss of hormone binding specificity. It was observed that in most of the cases, the receptor was activated by hCG or TSH or by both. In women, such mutations resulted in sOHSS.

The polymorphic nature of the FSHR gene is being explored to develop molecular markers mainly in the case of women undergoing controlled ovarian hyperstimulation protocol during IVF procedure. SNPs at -29 , 307 , and 680 have been studied in detail by various investigators in different ethnic populations. Polymorphism at -29 (AA) has been linked to poor ovarian response, which is found to be due to reduced expression of the receptor both at transcript and protein levels. On the other hand, mechanisms involved in the association of the altered ovarian response with SNP at 307 and 680 position is not well understood and efforts need to be made toward this. It would be interesting to study these SNPs in combination with each other with an aim to increase the predictive value of the marker. Preliminary findings from the analysis of data in women $(n=150)$ suggest that $A^{-29} \mathrm{~A} / \mathrm{Asn}^{680} \mathrm{Asn}$ genotype is associated with poor ovarian response with an odds ratio of 7.92 $(P=0.009)$ (Desai et al. 2013). Thus, studying SNPs of the FSHR gene is emerging as an important arm of pharmacogenomics and personalized medicine and needs to be explored further to optimize the dose of $\mathrm{FSH}$ required for superovulation and also to predict the ovarian response in women undergoing FSH treatment.

\section{Declaration of interest}

The authors declare that there is no conflict of interest that could be perceived as prejudicing the impartiality of this review.

\section{Funding}

The work carried out in authors' laboratory is supported by Indian Council of Medical Research, New Delhi, India (NIRRH/MS/103/2013) and (BIC/12(10)/2013). S S Desai is a recipient of Senior Research Fellowship of Indian Council of Medical Research, New Delhi, India.

\section{References}

Achrekar SK, Modi DN, Desai SK, Mangoli VS, Mangoli RV \& Mahale SD 2009a Follicle-stimulating hormone receptor polymorphism (Thr307Ala) is associated with variable ovarian response and ovarian hyperstimulation syndrome in Indian women. Fertility and Sterility 91 432-439. (doi:10.1016/j.fertnstert.2007.11.093)

Achrekar SK, Modi DN, Desai SK, Mangoli VS, Mangoli RV \& Mahale SD $2009 \mathrm{~b}$ Poor ovarian response to gonadotrophin stimulation is associated with FSH receptor polymorphism. Reproductive BioMedicine Online 18 509-515. (doi:10.1016/S1472-6483(10)60127-7)

Achrekar SK, Modi DN, Meherji PK, Patel ZM \& Mahale SD 2010 Follicle stimulating hormone receptor gene variants in women with primary and secondary amenorrhea. Journal of Assisted Reproduction and Genetics 27 317-326. (doi:10.1007/s10815-010-9404-9)

Ahda Y, Gromoll J, Wunsch A, Asatiani K, Zitzmann M, Nieschlag E \& Simoni M 2005 Follicle-stimulating hormone receptor gene haplotype distribution in normozoospermic and azoospermic men. Journal of Andrology 26 494-499. (doi:10.2164/jandrol.04186)

Aittomäki K, Dieguez Lucena J, Pakarinen P, Sistonen P, Tapanainen J, Gromoll J, Kaskikari R, Sankila E, Lehväslaiho H, Engel A et al. 1995 Mutation in the follicle-stimulating hormone receptor gene causes hereditary hypergonadotropic ovarian failure. Cell 82 959-968. (doi:10.1016/0092-8674(95)90275-9)

Allen L, Achermann J, Pakarinen P, Kotlar T, Huhtaniemi I \& Jameson J 2003 A novel loss of function mutation in exon 10 of the FSH receptor gene causing hypergondotrophic hypogonadism: clinical and molecular characteristics. Human Reproduction 18 251-256. (doi:10.1093/humrep/deg046)

Altmäe S, Hovatta O, Stavreus-Evers A \& Salumets A 2011 Genetic predictors of controlled ovarian hyperstimulation: where do we stand today? Human Reproduction Update 17 813-828. (doi:10.1093/ humupd/dmr034)

Beau I, Touraine P, Meduri G, Gougeon A, Desroches A \& Matuchansky C 1998 A novel phenotype related to partial loss of function mutations of the follicle stimulating hormone receptor. Journal of Clinical Investigation 102 1352-1359. (doi:10.1172/JCl3795)

Behre H, Greb R, Mempel A, Sonntag B, Kiesel L \& Kaltwasser P 2005 Significance of a common single nucleotide polymorphism in exon 10 of the follicle-stimulating hormone (FSH) receptor gene for the ovarian response to FSH: a pharmacogenetic approach to controlled ovarian hyperstimulation. Pharmacogenetics and Genomics 15 451-456. (doi:10.1097/01.fpc.0000167330.92786.5e)

Boudjenah R, Molina-Gomes D, Torre A, Bergere M, Bailly M, Boitrelle F, Taieb S, Wainer R, Benahmed M, de Mazancourt P et al. 2012 Genetic polymorphisms influence the ovarian response to $\mathrm{rFSH}$ stimulation in patients undergoing in vitro fertilization programs with ICSI. PLOS ONE 7 e38700. (doi:10.1371/journal.pone.0038700) 
Cai J, Lou H, Dong M, Lu XE, Zhu YM, Gao HJ \& Huang HF 2007 Poor ovarian response to gonadotropin stimulation is associated with low expression of follicle-stimulating hormone receptor in granulosa cells. Fertility and Sterility 87 1350-1365. (doi:10.1016/j.fertnstert.2006.11.034)

Casas-González P, Scaglia HE, Pérez-Solís MA, Durand G, Scaglia J, Zariñán T, Dias JA, Reiter E \& Ulloa-Aguirre A 2012 Normal testicular function without detectable follicle-stimulating hormone. A novel mutation in the follicle-stimulating hormone receptor gene leading to apparent constitutive activity and impaired agonist-induced desensitization and internalization. Molecular and Cellular Endocrinology 364 71-82. (doi:10.1016/j.mce.2012.08.011)

de-Castro F, Morón FJ, Montoro L, Galán JJ, Hernández DP, Padilla ES, Ramírez-Lorca R, Real LM \& Ruiz A 2004 Human controlled ovarian hyperstimulation outcome is a polygenic trait. Pharmacogenetics $\mathbf{1 4}$ 285-293. (doi:10.1097/00008571-200405000-00003)

Daelemans C, Smits G, de Maertelaer V, Costagliola S, Englert Y \& Vassart G 2004 Prediction of severity of symptoms in iatrogenic ovarian hyperstimulation syndrome by follicle-stimulating hormone receptor Ser ${ }^{680}$ Asn polymorphism. Journal of Clinical Endocrinology and Metabolism 89 6310-6315. (doi:10.1210/jc.2004-1044)

Davis D, Liu X \& Segaloff D 1995 Identification of the sites of N-linked glycosylation on the follicle-stimulating hormone (FSH) receptor and assessment of their role in FSH receptor function. Molecular Endocrinology 9 159-170. (doi:10.1210/me.9.2.159)

De-Leener A, Montanelli L, Van Durme J, Chae H, Smits G, Vassart G \& Costagliola S 2006 Presence and absence of follicle-stimulating hormone receptor mutations provide some insights into spontaneous ovarian hyperstimulation syndrome physiopathology. Journal of Clinical Endocrinology and Metabolism 91 555-562. (doi:10.1210/jc.2005-1580)

De-Leener A, Caltabiano G, Erkan S, Idil M, Vassart G \& Pardo L 2008 Identification of the first germline mutation in the extracellular domain of the follitropin receptor responsible for spontaneous ovarian hyperstimulation syndrome. Human Mutation 29 91-98. (doi:10REF20=10.1073/ pnas.95.23.13612)

Desai SS, Achrekar SK, Pathak BR, Desai SK, Mangoli VS, Mangoli RV \& Mahale SD 2011 Follicle-stimulating hormone receptor polymorphism (G-29A) is associated with altered level of receptor expression in granulosa cells. Journal of Clinical Endocrinology and Metabolism 96 2805-2812. (doi:10.1210/jc.2011-1064)

Desai SS, Achrekar SK, Paranjape SR, Desai SK, Mangoli VS \& Mahale SD 2013 Association of allelic combinations of FSHR gene polymorphisms with ovarian response FSHR gene polymorphisms. Reproductive BioMedicine Online 27 400-406. (doi:10.1016/j.rbmo.2013.07.007)

Dierich A, Sairam R, Monaco L, Fimia M, Gansmuller A, LeMeur M \& Sassone-Corsi P 1998 Impairing follicle-stimulating hormone (FSH) signaling in vivo: targeted disruption of the FSH receptor leads to aberrant gametogenesis and hormonal imbalance. PNAS 95 13612-13617. (doi:10.1073/pnas.95.23.13612)

Doherty E, Pakarinen P, Tiitinen A, Kiilavuori A, Huhtaniemi I \& Forrest $S$ 2002 A novel mutation in the FSH receptor inhibiting signal transduction and causing primary ovarian failure. Journal of Clinical Endocrinology and Metabolism 87 1151-1155. (doi:10.1210/jc.87.3.1151)

Dolfin E, Guani B, Lussiana C, Mari C, Restagno G \& Revelli A 2011 FSHreceptor Ala307Thr polymorphism is associated to polycystic ovary syndrome and to a higher responsiveness to exogenous FSH in Italian women. Journal of Assisted Reproduction and Genetics 28 925-930. (doi:10.1007/s10815-011-9619-4)

Du J, Zhang W, Guo L, Zhang Z, Shi H, Wang J, Zhang H, Gao L, Feng G \& He L 2010 Two FSHR variants, haplotypes and meta-analysis in Chinese women with premature ovarian failure and polycystic ovary syndrome. Molecular Genetics and Metabolism 100 292-295. (doi:10.1016/j. ymgme.2010.03.018)

Dufau L, Tsai-Morris H, Hu Z \& Buczko E 1995 Structure and regulation of the luteinizing hormone receptor gene. Journal of Steroid Biochemistry and Molecular Biology 53 283-291.

Fan QR \& Hendrickson WA 2005 Structure of human follicle-stimulating hormone in complex with its receptor. Nature 433 269-277. (doi:10.1038/nature03206)

Ferlin A, Pengo M, Selice R, Salmaso L, Garolla A \& Foresta C 2008 Analysis of single nucleotide polymorphisms of FSH receptor gene suggests association with testicular cancer susceptibility. EndocrineRelated Cancer 15 429-437. (doi:10.1677/ERC-07-0257)
Gerasimova T, Thanasoula MN, Zattas D, Seli E, Sakkas D \& Lalioti MD 2010 Identification and in vitro characterization of follicle stimulating hormone $(\mathrm{FSH})$ receptor variants associated with abnormal ovarian response to FSH. Journal of Clinical Endocrinology and Metabolism 95 529-536. (doi:10.1210/jc.2009-1304)

Goodarzi MO, Dumesic DA, Chazenbalk G \& Azziz R 2011 Polycystic ovary syndrome: etiology, pathogenesis and diagnosis. Nature Reviews. Endocrinology 7 219-231. (doi:10.1038/nrendo.2010.217)

Greb RR, Grieshaber K, Gromoll J, Sonntag B, Nieschlag E, Kiesel L \& Simoni M 2005 A common single nucleotide polymorphism in exon 10 of the human follicle stimulating hormone receptor is a major determinant of length and hormonal dynamics of the menstrual cycle. Journal of Clinical Endocrinology and Metabolism 90 4866-4872.

Gromoll J, Gudermann T \& Nieschlag E 1992 Molecular cloning of a truncated isoform of the human follicle stimulating hormone receptor. Biochemical and Biophysical Research Communications $\mathbf{1 8 8}$ 1077-1083. (doi:10.1016/0006-291X(92)91341-M)

Gromoll J, Dankbar B \& Gudermann T 1994 Characterization of the 5' flanking region of the human follicle-stimulating hormone receptor gene. Molecular and Cellular Endocrinology 102 93-102. (doi:10.1016/03037207(94)9REF30=10.1016/0006-291X(92)91341-M)

Gromoll J, Pekel E \& Nieschlag E 1996 The structure and organization of the human follicle-stimulating hormone receptor gene. Genomics 35 308-311. (doi:10.1006/geno.1996.0361)

Gromoll J, Schulz A, Borta H, Gudermann T, Teerds KJ, Greschniok A, Nieschlag E \& Seif FJ 2002 Homozygous mutation within the conserved Ala-Phe-Asn-Glu-Thr motif of exon 7 of the LH receptor causes male pseudohermaphroditism. European Journal of Endocrinology 147 597-608. (doi:10.1530/eje.0.1470597)

Janovick JA, Maya-Núñez G, Ulloa-Aguirre A, Huhtaniemi IT, Dias JA, Verbost P \& Conn PM 2009 Increased plasma membrane expression of human follicle-stimulating hormone receptor by a small molecule thienopyr(im)idine. Molecular and Cellular Endocrinology 298 84-88. (doi:10.1016/j.mce.2008.09.0REF34=10.1016/j.mce.2008.09.015)

Jiang X, Liu H, Chen X, Chen PH, Fischer D, Sriraman V, Yu HN, Arkinstall S \& He X 2012 Structure of follicle-stimulating hormone in complex with the entire ectodomain of its receptor. PNAS 109 12491-12496. (doi:10.1073/pnas.1206643109)

Kim S, Pyun JA, Cha DH, Ko JJ \& Kwack K 2011 Epistasis between FSHR and CYP19A1 polymorphisms is associated with premature ovarian failure. Fertility and Sterility 95 2585-2588. (doi:10.1016/j.fertnstert.2010. 12.042)

Klingman I \& Rosenwaks Z 2001 Differentiating clinical profiles: predicting good responders, poor responders, and hyper responders. Fertility and Sterility 76 1185-1190. (doi:10.1016/S0015-0282(01)02893-X)

Klinkert ER, Velde ER, Weima S, van-Zandvoort PM, Hanssen RG, Nilsson PR, de-Jong FH, Looman CW \& Broekmans FJ 2006 FSH receptor genotype is associated with pregnancy but not with ovarian response in IVF. Reproductive BioMedicine Online 13 687-695. (doi:10. 1016/S1472-6483(10)60660-8)

Kuechler A, Hauffa BP, Köninger A, Kleinau G, Albrecht B, Horsthemke B \& Gromoll J 2010 An unbalanced translocation unmasks a recessive mutation in the follicle-stimulating hormone receptor (FSHR) gene and causes FSH resistance. European Journal of Human Genetics 18 656-661. (doi:10.1038/ejhg.2009.244)

Kumar TR, Wang Y, Lu N \& Matzuk MM 1997 Follicle stimulating hormone is required for ovarian follicle maturation but not male fertility. Nature Genetics 15 201-204. (doi:10.1038/ng0297-201)

Laan M, Grigorova M \& Huhtaniemi IT 2012 Pharmacogenetics of follicle-stimulating hormone action. Current Opinion in Endocrinology, Diabetes, and Obesity 19 220-227. (doi:10.1097/MED.0b013 e3283534b11)

Laue L, Chan W-Y, Hsueh AJW, Kudo M, Hsu SY, Wu S-M, Blomberg L \& Cutler GB Jr 1995 Genetic heterogeneity of constitutively activating mutations of the human luteinizing hormone receptor in familial malelimited precocious puberty. PNAS 92 1906-1910. (doi:10.1073/ pnas.92.6.1906)

Laven JS, Mulders AG, Suryandari DA, Gromoll J, Nieschlag E, Fauser BC \& Simoni M 2003 Follicle-stimulating hormone receptor polymorphisms in women with normogonadotropic anovulatory infertility. Fertility and Sterility 80 986-992. (doi:10.1016/S0015-0282(03)01115-4) 
Lend AK, Belousova A, Haller-Kikkatalo K, Punab $M$, Poolamets $O$, Peters M \& Salumets A 2010 Follicle-stimulating hormone receptor gene haplotypes and male infertility in Estonian population and meta-analysis. Systems Biology in Reproductive Medicine 56 84-90. (doi:10.3109/ 19396360903456676)

Li Y, Gu A, Yang H, Ding X, Ji G, Lu C, Xia Y, Song L \& Wang X 2011 FSH receptor gene polymorphisms in fertile and infertile Han-Chinese males. Clinica Chimica Acta 412 1048-1052. (doi:10.1016/j.cca.2011.02.016)

Lindgren I, Giwercman A, Axelsson J \& Lundberg Giwercman Y 2012 Association between follicle-stimulating hormone receptor polymorphisms and reproductive parameters in young men from the general population. Pharmacogenetics and Genomics 22 667-672. (doi:10.1097/FPC.0b013e3283566c42)

Loutradis D, Patsoula E, Minas V, Koussidis GA, Antsaklis A, Michalas S \& Makrigiannakis A $2006 \mathrm{FSH}$ receptor gene polymorphisms have a role for different ovarian response to stimulation in patients entering IVF/ICSIET programs. Journal of Assisted Reproduction and Genetics 23 177-184. (doi:10.1007/s10815-005-9015-z)

Ludwig AH, Murawska M, Panek G, Timorek A \& Kupryjanczyk J 2009 Androgen, progesterone, and FSH receptor polymorphisms in ovarian cancer risk and outcome. Endocrine-Related Cancer 16 1005-1016. (doi:10.1677/ERC-08-0135)

Meduri G, Touraine P, Beau I, Lahuna O, Desroches A \& Vacher-Lavenu C 2003 Delayed puberty and primary amenorrhea associated with a novel mutation of the human follicle-stimulating hormone receptor: clinical, histological, and molecular studies. Journal of Clinical Endocrinology and Metabolism 88 3491-3498. (doi:10.1210/jc.2003-030217)

Meehan TP \& Narayan P 2007 Top of form constitutively active luteinizing hormone receptors: consequences of in vivo expression. Molecular and Cellular Endocrinology 2 294-300. (doi:10.1016/j.mce.2006.03. 04REF50 $=10.1016 /$ j.mce.2006.03.045)

Minegishi T, Igarashi S, Nakamura K, Nakamura M, Tano M, Shinozaki H, Miyamoto K \& Ibuki Y 1994 Functional expression of the recombinant human FSH receptor. Journal of Endocrinology 141 369-375. (doi:10.1677/joe.0.1410369)

Mohiyiddeen L, Newman WG, McBurney H, Mulugeta B, Roberts SA \& Nardo LG 2012 Follicle-stimulating hormone receptor gene polymorphisms are not associated with ovarian reserve markers. Fertility and Sterility 97 677-681. (doi:10.1016/j.fertnstert.2011.12.040)

Montanelli L, Van Durme J, Smits G, Bonomi M, Rodien P, Devor J, MoffatWilson K, Pardo L, Vassart G \& Costagliola S 2004 Modulation of ligand selectivity associated with activation of the transmembrane region of the human follitropin receptor. Molecular Endocrinology 18 2061-2073. (doi:10.1210/me.2004-0036)

Morón FJ \& Ruiz A 2010 Pharmacogenetics of controlled ovarian hyperstimulation: time to corroborate the clinical utility of FSH receptor genetic markers. Pharmacogenomics 11 1613-1618. (doi:10.2217/ pgs.10.156)

Nakamura Y, Maekawa R, Yamagata Y, Tamura I \& Sugino N 2008 A novel mutation in exon 8 of the follicle-stimulating hormone receptor in a women with primary amenorrhea. Gynecological Endocrinology 24 708-712. (doi:10.1080/09513590802454927)

Nakayama T, Kuroi N, Sano M, Tabara Y, Katsuya T, Ogihara T, Makita Y, Hata A, Yamada M, Takahashi N et al. 2006 Mutation of the folliclestimulating hormone receptor gene $5^{\prime}$-untranslated region associated with female hypertension. Hypertension 48 512-518. (doi:10.1161/01. HYP.0000233877.84343.d7)

Nardo LG, Yates AP, Roberts SA, Pemberton P \& Laing I 2009 The relationships between $\mathrm{AMH}$, androgens, insulin resistance and basal ovarian follicular status in non-obese subfertile women with and without polycystic ovary syndrome. Human Reproduction 24 2917-2923. (doi:10.1093/humrep/dep225)

Nieschlag E, Simoni M, Gromoll J \& Weinbauer GF 1999 Role of FSH in the regulation of spermatogenesis: clinical aspects. Clinical Endocrinology 51 139-146. (doi:10.1046/j.1365-2265.1999.00846.x)

Nordhoff V, Sonntag B, von Tils D, Götte M, Schüring AN, Gromoll J, Redmann K, Casarini L \& Simoni M 2011 Effects of the FSH receptor gene polymorphism p.N680S on CAMP and steroid production in cultured primary human granulosa cells. Reproductive BioMedicine Online 23 196-203. (doi:10.1016/j.rbmo.2011.04.009REF61=)

Okada T, Sugihara M, Bondar AN, Elstner M, Entel P \& Buss V 2004 The retinal conformation and its environment in rhodopsin in light of a new 2.2 A crystal structure. Journal of Molecular Biology 342 571-583. (doi:10.1016/j.jmb.2004.07.0REF63=10.1016/S14726483(10)61026-7)

Orio F Jr, Ferrarini E, Cascella T, Dimida A, Palomba S, Gianetti E, Colao A, Agretti P, Vitti P, Lombardi G et al. 2006 Genetic analysis of the follicle stimulating hormone receptor gene in women with polycystic ovary syndrome. Journal of Endocrinological Investigation 29 975-982.

Overbeek A, Kuijper EA, Hendriks ML, Blankenstein MA, Ketel IJ, Twisk JW, Hompes PG, Homburg R \& Lambalk CB 2009 Clomiphene citrate resistance in relation to follicle-stimulating hormone receptor Ser ${ }^{680}$ Ser-polymorphism in polycystic ovary syndrome. Human Reproduction 24 2007-2013. (doi:10.1093/humrep/dep114)

Pengo M, Ferlin A, Arredi B, Ganz F, Selice R, Garolla A \& Foresta C 2006 FSH receptor gene polymorphisms in fertile and infertile Italian men. Reproductive BioMedicine Online 13 795-800. (doi:10.1016/ S1472-6483(10)61026REF67=10.1006/geno.1993.1041)

Perez-Mayorga M, Gromoll J, Behre HM, Gassner C, Nieschlag E \& Simoni M 2000 Ovarian response to follicle-stimulating hormone (FSH) stimulation depends on the FSH receptor genotype. Journal of Clinical Endocrinology and Metabolism 85 3365-3369. (doi:10.1210/jc.85.9.3365)

Pierce JG \& Parsons TF 1981 Glycoprotein hormones: structure and function. Annual Review of Biochemistry 50 465-495. (doi:10.1146/ annurev.bi.50.070181.002341)

Richards JS \& Midgley AR 1976 Protein hormone action: a key to understanding ovarian follicular and luteal cell development. Biology of Reproduction 14 82-94. (doi:10.1095/biolreprod14.1.82)

Rousseau-Merck MF, Atger M, Loosfelt H, Milgrom E \& Berger R 1993 The chromosomal localization of the human follicle-stimulating hormone receptor gene (FSHR) on 2p21-p16 is similar to that of the luteinizing hormone receptor gene. Genomics 15 222-224. (doi:10.1006/geno. 1993.1041)

Russo D, Arturi F, Suarez HG, Schlumberger M, Du Villard JA, Crocetti U \& Filetti S 1996 Thyrotropin receptor gene alterations in thyroid hyperfunctioning adenomas. Journal of Clinical Endocrinology and Metabolism 81 1548-1551. (doi:10.1210/jc.81.4.1548)

Ryan L, Feng X, d'Alva B, Zhang M, Van Voorhis J \& Pinto M 2007 Evaluating the roles of follicle-stimulating hormone receptor polymorphisms in gonadal hyperstimulation associated with sever juvenile primary hypothyrodism. Journal of Clinical Endocrinology and Metabolism 92 2312-2317. (doi:10.1210/jc.2006-2086)

Sairam MR, Jiang LG, Yarney TA \& Khan H 1996 Follitropin signal transduction: alternative splicing of the FSH receptor gene produces a dominant negative form of receptor which inhibits hormone action. Biochemical and Biophysical Research Communications 226 717-722. (doi:10.1006/bbrc.1996.1419)

Simoni M, Weinbauer F, Gromoll J \& Nieschlag E 1999 Role of FSH in male gonadal function. Annales d'Endocrinologie 60 102-106. (doi:AN-061999-60-2-0003-4266-101019-ART60)

Smits G, Olatunbosun O, Delbaere A, Pierson R \& Vassart G 2003 Ovarian hyperstimulation syndrome due to a mutation in the follicle-stimulating hormone receptor. New England Journal of Medicine 349 760-766. (doi:10.1056/NEJMoa030064)

Song GJ, Park YS, Lee YS, Lee CC \& Kang IS 2002 Alternatively spliced variants of the follicle-stimulating hormone receptor gene in the testis of infertile men. Fertility and Sterility 77 499-504. (doi:10.1016/ S0015-0282(01)03221-6)

Sprengel R, Braun T, Nikolics K, Segaloff DL \& Seeburg PH 1990 The testicular receptor for follicle-stimulating hormone: structure and functional expression of cloned cDNA. Molecular Endocrinology 4 525-530. (doi:10.1210/mend-4-4-525)

Sudo S, Kudo M, Wada S, Sato O, Hsueh J \& Fujimoto S 2002 Genetic and functional analyses of polymorphism in the human FSH receptor gene. Molecular Human Reproduction 8 893-899. (doi:10.1093/molehr/8.10. 893)

Tapanainen J, Aittomäki K, Min J, Vaskivuo T \& Huhtaniemi I 1997 Men homozygous for an inactivating mutation of the follicle-stimulating hormone $(\mathrm{FSH})$ receptor gene present variable suppression of spermatogenesis and fertility. Nature Genetics 15 205-206. (doi:10.1038/ng0297-205)

Tilly L, Kowalski I, Schomberg W \& Hsueh J 1992 Apoptosis in atretic ovarian follicles is associated with selective decreases in messenger ribonucleic acid transcripts for gonadotropin receptors and cytochrome P450 aromatase. Endocrinology 131 1670-1676. (doi:10.1210/en.131.4.1670) 
Touraine P, Beau I, Gougeon A, Meduri G, Desroches A \& Pichard C 1999 New natural inactivating mutations of the follicle-stimulating hormone receptor: correlations between receptor function and phenotype. Molecular Endocrinology 13 1844-1854. (doi:10.1210/me.13.11.1844)

Tüttelmann F, Rajpert-De Meyts E, Nieschlag E \& Simoni M 2007 Gene polymorphisms and male infertility - a meta-analysis and literature review. Reproductive BioMedicine Online 15 643-658. (doi:10.1016/ S1472-6483(10)60531-7)

Vasseur C, Rodien P, Beau I, Desroches A, Gérard C \& de Poncheville L 2003 A chorionic gonadotropin-sensitive mutation in the folliclestimulating hormone receptor as a cause of familial gestational spontaneous ovarian hyperstimulation syndrome. New England Journal of Medicine 349 753-759. (doi:10.1056/NEJMoa030065)

Wu W, Cai H, Sun H, Lu J, Zhao D, Qin Y, Han X, Niu X, Lu C, Xia Y et al. 2012 Follicle stimulating hormone receptor G-29A, 919A > G, 2039A> $\mathrm{G}$ polymorphism and the risk of male infertility: a meta-analysis. Gene 505 388-392. (doi:10.1016/j.gene.2012.02.023)

Wunsch A, Ahda Y, Banaz-Yaşar F, Sonntag B, Nieschlag E, Simoni M \& Gromoll J 2005 Single-nucleotide polymorphisms in the promoter region influence the expression of the human follicle-stimulating hormone receptor. Fertility and Sterility 84 446-453. (doi:10.1016/j.fertnstert.2005.02.031)

Yao Y, Ma CH, Tang HL \& Hu YF 2011 Influence of follicle-stimulating hormone receptor (FSHR) Ser ${ }^{680}$ Asn polymorphism on ovarian function and in-vitro fertilization outcome: a meta-analysis. Molecular Genetics and Metabolism 103 388-393. (doi:10.1016/j.ymgme.2011.04.005)
Yarney TA, Jiang L, Khan H, MacDonald EA, Laird DW \& Sairam MR 1997 Molecular cloning, structure, and expression of a testicular follitropin receptor with selective alteration in the carboxy terminus that affects signaling function. Molecular Reproduction and Development $\mathbf{4 8}$ 458-470. (doi:10.1002/(SICl)1098-2795(199712)48:4<458::AID-MRD6>3.0.CO;2-P)

Zalewski G, Wołczyński S \& Chyczewski L 2013 Association of rs6166 polymorphism with FSH receptor transcript variants and steroid production in human granulosa cell cultures. Systems Biology in Reproductive Medicine 59 191-198. (doi:10.3109/19396368.2012. 745035)

Zarinan T, Perez-Solis MA, Maya-Nunez G, Casas-Gonzalez P, Conn PM, Dias JA \& Ulloa-Aguirre A 2010 Dominant negative effects of human follicle-stimulating hormone receptor expression-deficient mutants on wild-type receptor cell surface expression. Rescue of oligomerizationdependent defective receptor expression by using cognate decoys. Molecular and Cellular Endocrinology 321 112-122. (doi:10.1016/ j.mce.2010.02.027)

Received 31 July 2013

First decision 4 September 2013

Revised manuscript received 16 September 2013

Accepted 19 September 2013 